\title{
Enneking Stage IIA
}

National Cancer Institute

\section{Source}

National Cancer Institute. Enneking Stage IIA. NCI Thesaurus. Code C146703.

A stage for malignant musculoskeletal tumors characterized by high grade (G2), intracomparmental site ( $\mathrm{T} 1$ ), and no metastasis (M0). 